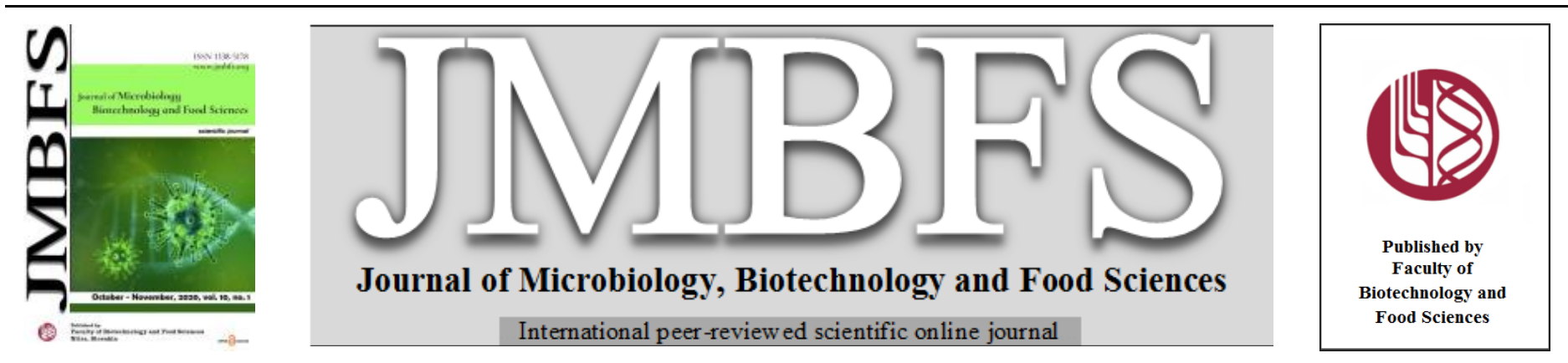

\title{
COMPARATIVE STUDY ON BIOSYNTHESIS OF VALUABLE ANTIMICROBIAL AND ANTITUMOR NANO-SILVER USING FRESH WATER GREEN AND BLUE-GREEN MICROALGAE
}

\author{
Reem M. Alharbi ${ }^{1}$, Ahmed AF. Soliman ${ }^{2}$, Abeer A. Abd El Aty ${ }^{1,3 *}$ \\ Address(es): \\ ${ }^{1}$ Department of Biology, College of Science, University of Hafr Al Batin, P.O. Box 1803, Hafr Al Batin, Saudi Arabia. \\ ${ }^{2}$ Drug Bioassay-Cell Culture Laboratory, Pharmacognosy Department, National Research Center, Dokki, Giza, 12622, Egypt. \\ ${ }^{3}$ Chemistry of Natural \& Microbial Products department, National Research Centre, Dokki, Giza, 12622, Egypt.
}

*Corresponding author: aabass44@yahoo.com , abeerab@uhb.edu.sa

doi: 10.15414/jmbfs.2020.10.2.249-256

\section{ARTICLE INFO}

Received 22. 6. 2019

Revised 13. 6. 2020

Accepted 25. 6. 2020

Published 1. 10. 2020

Regular article

OPEN $\partial_{\text {ACCESS }}$

\begin{abstract}
Two levels Plackett-Burman experimental design was employed to screen the main factors that significantly affect the synthesis of bioactive silver nanoparticles. Scenedesmus obliquиs ethanol extract, Scenedesmus obliquus dried algal powder and Spirulina platensis aqueous extract were the most favorable reducing and capping agents. Also the high $\mathrm{pH}$ value (10), rpm (150), high concentration of $\mathrm{AgNO}_{3}(4 \mathrm{mM})$ and dark conditions had the highest significant influence on biosynthesis of active nanoparticles. Characterizations of the formed AgNPs were approved by UV-Visible Spectroscopy, Transmission Electron Microscopy and Fourier Transform Infrared spectroscopy. The nanoparticles were varied in sizes and shape that ranged between 2.83 and $27.17 \mathrm{~nm}$, depending on the organism used and the method of biosynthesis. Valuable inhibitory effects were showed by all bio-synthesized nanoparticles against four tested Grampositive and Gram- negative bacteria, except that formed by Spirulina platensis powder. Moreover, the nanoparticles exhibited wide range of antifungal activities. AgNPs prepared from ethanol extract of Spirulina platensis was the most active against HepG2 and MCF7 cell lines, with $\mathrm{IC}_{50}$ values 62.1 and $56.2 \mathrm{ug} / \mathrm{mL}$, respectively. The obtained results, indicated the advantages of AgNPs from microalgae and possible industrial applications as a source of antifungal, antibacterial, and antitumor formulation.
\end{abstract}

Keywords: Plackett-Burman design, Biosynthesis, AgNPs, Microalgae, Antimicrobial, Antitumor

\section{INTRODUCTION}

Modern sciences deal with nanotechnology as one of the most important and active area of research. According to (Dahl $\boldsymbol{e t}$ al., 2007) silver nanoparticles in range from 1 to $100 \mathrm{~nm}$, usually have interesting with valuable applications in nanotechnology. Synthesis of silver nano-particles had received attentiveness due to their outstanding properties and different applications in water treatment (Con and Loan, 2011). Also silver nano-particles showed possible applications in catalysis as mentioned by (Paul $\boldsymbol{e t}$ al., 2014) and plasmonics (Khlebtsov and Dykman, 2010), optoelectronics (Muruganandam et al., 2014), pharmaceutica applications (Ravichandran, 2009) and biological sensor (Venkatesan and Santhanalakshmi, 2014). AgNPs with many advantages of, compatibility and eco-friendliness for different pharmaceutical and medical applications can be synthesized from different biological materials like plant extract according to (Sinha and Paul, 2014), also (Sinha et al., 2015) and (Kannan et al., 2013) respectively indicated that fresh water algae and algae from marine sources can be used for the synthesis of AgNPs, without addition of any harmful chemicals for the synthesis process. Fresh water microalgae extracts exposed high amounts of terpenoids, tannins, saponins, steroid, carbohydrate and proteins that can serve as effective metal reducing and capping agent's, to supply a robust coating on the metal nanoparticles in a single step (Sinha et al., 2015).

The resistance of many microbial diseases to synthetic drugs gradually increased, therefore an urgent need to develop new antitumor, antifungal and antibacterial agents. Biosynthesis of nanoparticles using algae from marine sources has been extensively investigated for their activities as an antimicrobial agent (Kumar $\boldsymbol{e t}$ al., 2013; Prasad et al., 2013). On the other hand, reports on fresh water algae are lacking. Therefore, the main object of our research is the application of a statistical method to evaluate main factors affecting the green-synthesis of biologically active AgNPs from Scenedesmus obliquus and Spirulina platensis fresh water microalgae and to investigate the effect of different methods of extraction on the size, shape and biological activity of the biosynthesized nanoparticles.

\section{MATERIALS AND METHODS}

\section{Algal materials used for biosynthesis of AgNPs}

Green alga (Scenedesmus obliquus) and blue green alga (Spirulina platensis were obtained from the Algae Development Unit of National Research Centre Cairo, Egypt. Algal materials were prepared according to (Sinha et al., 2015) Algae washed using distilled water and shade-dried for 5 days also oven dried at $60^{\circ} \mathrm{C}$ until constant weight was obtained. Then ground into fine powder using electric mixer and stored at $4^{\circ} \mathrm{C}$.

\section{Plackett-Burman design (PBD)}

Plackett-Burman experimental design (Abd El Aty et al., 2016\& 2018) was used to evaluate the relative importance of various factors for biological synthesis of AgNPs. Eleven variables ( $S$. obliquus ethanol extract, $S$. obliquus aqueous extract, $S$. obliquus dried algal powder, $S$. platensis dried algal powder, $S$ platensis ethanol extract, $S$. platensis aqueous extract, Temperature, AgNO3 concentration, RPM, pH value, Incubation conditions light (1)/ dark (0) and Incubation period) were selected for the study, each variable was represented at two levels, high concentration $(+1)$ and low concentration $(-1)$ as shown in Table 1. Tested factors represented in twelve trials Plackett-Burman experimental design with the response (AgNPs biological activity against E.coli). All experiments were carried out in duplicate and the average activity was taken as the response. Plackett-Burman experimental design is based on the first order linear model (Plackett and Burman , 1946):

$\mathrm{Y}=\mathrm{B} 0+\sum \mathrm{BiXi}$ Eq. (1)

$\mathrm{Y}$ is the response (Inhibition zone diameter, IZD), B0 is the model intercept and $\mathrm{Bi}$ is the variables estimates. The effect of each variable was determined by the following equation, 
$\mathrm{E}(\mathrm{Xi})$ is the effect of the tested variable. $\mathrm{Mi}+$ and $\mathrm{Mi}-$ represent $\mathrm{IZD}(\mathrm{mm})$ from the trials where the variable $(\mathrm{Xi})$ measured was present at high and low concentrations, respectively and $\mathrm{N}$ is the number of trials in Eq. (2). Statistical analysis of PBD is performed by using Design-Expert ${ }^{\circledR} 8$ software from StatEase, Inc.

\section{Biosynthesis of silver nanoparticles}

According to Plackett-Burman design the green synthesis of AgNPs was carried out using three different methods.

\section{Biosynthesis of AgNPs by the algal powder}

The reaction mixture contained $1 \mathrm{~g}$ of $S$. obliquus and S. platensis dry matter and $50 \mathrm{~mL}$ of $4 \mathrm{mM} \mathrm{AgNO}$ aqueous solution, and incubated at $30^{\circ} \mathrm{C}$ for $24 \mathrm{~h}$ with the continuous stirring condition. The change in color was envisaged as the evidence of bioreduction (Meena et al., 2007; Abdel-Raouf et al., 2018).

\section{Biosynthesis of AgNPs by the algal aqueous extract}

About $5 \mathrm{~g}$ of dried $S$. obliquus and S. platensis separately with $50 \mathrm{~mL}$ of sterilized distilled water were boiled for $15 \mathrm{~min}$ at $60^{\circ} \mathrm{C}$. and filtered with Whatman no. 1 filter paper. Equal volumes of the filtrate and $4 \mathrm{mM} \mathrm{AgNO}$ aqueous solution were mixed in an Erlenmeyer flask and incubated at $30^{\circ} \mathrm{C}$ for 24h. (Sinha et al., 2015).

\section{Biosynthesis of AgNPs by the algal ethanol extract}

The extraction was achieved using the solvent ethanol according to Abdel-Raouf et al. (2018) with some modifications. About $5 \mathrm{~g}$ of the dried finally powdered algal biomass was added to $100 \mathrm{~mL}$ solvent in a $250 \mathrm{~mL}$ Erlenmeyer flask. The extraction was executed on a sonication water bath for $30 \mathrm{~min}$. After them, all algal extracts were filtered and the solvents were evaporated at $50^{\circ} \mathrm{C} .50 \mathrm{~mL}$ of $4 \mathrm{mM}$ aqueous $\mathrm{AgNO}_{3}$ solution were added to dried sample and kept at $30^{\circ} \mathrm{C}$ for $24 \mathrm{~h}$.

\section{Characterization studies of biosynthesized silver nanoparticles}

The formation of AgNPs was confirmed by different analysis.

\section{Ultraviolet-visible spectral analysis}

The absorption spectrum of aliquots $(2 \mathrm{~mL})$ prepared by different method from both algae was scanned using UV-Visible spectrophotometer in the range of 200 $800 \mathrm{~nm}$. The sharp peak given by UV visible spectrum has indicated the formation of AgNPs at the absorption range 400 - $450 \mathrm{~nm}$ (Abd El Aty and Ammar, 2016).

Table 1 The Plackett-Burman design with eleven variables.

\begin{tabular}{llll} 
Variable & Variable & Level & \\
\cline { 3 - 4 } code & & Low(-1) & High(+1) \\
\hline A & So.EE $(\mathrm{mL})$ & 0 & 5 \\
B & So.AE $(\mathrm{mL})$ & 0 & 5 \\
C & So.DAP $(\mathrm{g})$ & 0 & 1 \\
D & Sp.DAP $(\mathrm{g})$ & 0 & 1 \\
E & Sp.EE $(\mathrm{mL})$ & 0 & 5 \\
F & Sp.AE $(\mathrm{mL})$ & 0 & 5 \\
G & Temperature $\left({ }^{\circ} \mathrm{C}\right)$ & 28 & 35 \\
H & AgNO 3 concentration $(\mathrm{mM})$ & 1 & 4 \\
J & pH value & 5 & 10 \\
K & Incubation conditions light $(1) /$ & 0 & 1 \\
& dark $(0)$ & & \\
L & RPM & 0 & 150
\end{tabular}

So.EE, S. obliquus ethanol extract; So.AE, S. obliquus aqueous extract; So.DAP, S. obliquus dried algal powder. Sp.DAP, S. platensis dried algal powder; Sp.EE S. platensis ethanol extract; Sp.AE, S. platensis aqueous extract. RPM, round /min.

\section{Transmission Electron Microcopy (TEM)}

The size and shape of nanoparticles were characterized by TEM (JEOL-2100) according to Shaheen and Abd El Aty, (2018).

\section{Fourier Transform Infrared Spectroscopy (FTIR)}

The Fourier transform infrared (FTIR) has been used to identify the probable biomolecules responsible for reduction, capping and effective stabilization of the nanoparticles using (FTIR-8300, Shimadzu, Japan), at a resolution of $2 \mathrm{~cm}$ over a wave number ranging from 400 to $4000-\mathrm{cm}$. finally the characteristic peaks were recorded.

\section{Application studies of biosynthesized silver nanoparticles. Screening of antibacterial activity}

The biosynthesized AgNps were screened in-vitro against different pathogenic strains of Gram-positive and Gram-negative bacteria by the agar well diffusion technique (Shaheen and Abd El Aty, 2018). $200 \mu \mathrm{l}$ of six nanoparticles colloidal solutions were evaluated against Gram-positive (Staphylococcus aureus ATCC29213 and Bacillus subtilis ATCC6633) and Gram-negative bacteria (Salmonella enterica ATCC25566 and Escherichia coli ATCC25922). Wells of about $10 \mathrm{~mm}$ in diameter were made in the solidified agar media inoculated with pathogen and filled with the nanoparticle colloids, and then they were left over night at $4{ }^{\circ} \mathrm{C}$ to allow the release of nanoparticles into the medium. After the incubation for $24 \mathrm{~h}$ at $30^{\circ} \mathrm{C}$ the inhibition zones were measured in (mm) as Mean $\pm \mathrm{SD}$

\section{Screening of antifungal activity}

The pathogenic (Candida albicans ATCC10321, Candida tropicalis ATCC750) and (Aspergillus niger NRC53, Fusarium solani NRC15) were analyzed by well diffusion method. Approximately $10 \mathrm{~mm}$ diameter of wells was made on the inoculated $\left(1 \times 10^{6}\right.$ spores $^{-\mathrm{ml})}$ potato dextrose agar (PDA) plate with the help of sterilized cork borer. $200 \mu \mathrm{l}$ of synthesized particles were inoculated to the wells and left over night at $4{ }^{\circ} \mathrm{C}$ to allow the release of nanoparticles into the medium. The plates were incubated in incubator for $72 \mathrm{~h}$ at $28{ }^{\circ} \mathrm{C}$ and the zones of inhibition were discussed as mentioned before (Abdel Wahab et al., 2018).

\section{Screening of cytotoxicity activity}

\section{Cell culture}

HepG2 (hepatocellular carcinoma) and MCF-7 (breast adenocarcinoma) were maintained in RPMI medium supplemented with $10 \%$ fetal bovine serum and incubated at $37{ }^{\circ} \mathrm{C}$ in $5 \% \mathrm{CO} 2$ and $95 \%$ humidity. Cells were sub-cultured using trypsin $0.15 \%$. All cell lines were purchased from Vacsera (Giza, Egypt) (Abd El Aty et al., 2020).

\section{Cell viability assay}

After $24 \mathrm{~h}$ of seeding 10000 cells per well in case of HepG2 and MCF-7 cel lines (in 96 well plates), the medium was changed to complete medium containing a final concentration of the extracts of $100 \mu \mathrm{g} / \mathrm{mLin}$ triplicates. The cells were treated for $48 \mathrm{~h}$. $100 \mu \mathrm{g} / \mathrm{mL}$ doxorubicin was used as positive control and $0.5 \%$ DMSO was used as negative control. Cell viability was determined using the MTT (3-(4, 5-dimethylthiazol-2-yl)-2, 5-diphenyltetrazolium bromide) assay as described by Mosmann $\boldsymbol{e t}$ al. (1983). The equation used for calculation of percentage cytotoxicity: $(1-(\operatorname{av}(\mathrm{x}) /(\operatorname{av}(\mathrm{NC}))) * 100$

Where Av: average, X: absorbance of sample well measured at $595 \mathrm{~nm}$ with reference $690 \mathrm{~nm}, \mathrm{NC}$ : absorbance of negative control measured at $595 \mathrm{~nm}$ with reference 690 .

\section{Determination of cytotoxicity activity IC50 values}

In case of most active nano-silver possessing high cytotoxicity on different cancer cell lines, different concentrations were prepared dose response study. The results were used to calculate the $\mathrm{IC}_{50}$ values of each AgNPs using probit analysis and utilizing the SPSS computer program (SPSS for windows, statistical analysis software package / version 9 / 1989 SPSS Inc., Chicago, USA).

\section{RESULTS AND DISCUSSION}

\section{Plackett-Burman design (PBD) for biosynthesis of silver nanoparticles}

The experimental design Plackett-Burman was applied to determine the most effective variables for obtaining biologically active silver nanoparticles. The response (R1) measured as inhibition zone diameter (IZD) in $\mathrm{mm}$ against the pathogenic Gram negative bacteria E.coli. Results shown in Figure 1 revealed that the variables (Sp.AE, $\mathrm{AgNO}_{3}$ concentration, So.EE, $\mathrm{pH}$ value and So.DAP) were significantly influence the synthesis of biologically active AgNPs. Results showed variations in the inhibition zone diameter (IZD) ranging from 11 to 27 $\mathrm{mm}$ as shown in Table 2. This variation in the biological activity (IZD) of AgNPs emphasizes the effect of different variables on the size, shape and biological activity of nanoparticles. Analysis of ANOVA explained that the Model F-value (59.02) is significant. The "Pred R-Squared" of 0.8972 is in reasonable agreement with the "Adj R-Squared "of 0.9597 (Table 3).

The first order model equation developed by PB design showed the dependence of nanosilver activity on the studied variables:

$\mathrm{R} 1(\mathrm{IZD}, \mathrm{mm})=+12.06+3.11 * \mathrm{~A}+1.06 * \mathrm{C}-2.38 * \mathrm{D}-3.57 * \mathrm{E}+7.38 * \mathrm{~F}-2.02 * \mathrm{G}$ 
$+5.47 * \mathrm{H}+2.72 * \mathrm{~J}-2.41 * \mathrm{~K}$

Eq. (3)

Out of PB results we found that $S$. obliquus ethanol extract (So.EE), S. obliquus dried algal powder (So.DAP) and S. platensis aqueous extract (Sp.AE) were the most favorable reducing agents. Also the high $\mathrm{pH}$ value (10), rpm (150), high concentration of AgNO3 (4 mM) and dark conditions had the highest significant influence on biosynthesis of active nanoparticles, as shown in trial 3 Table 2. According to results obtained from PB experiment different methods of biosynthesis should be applied to obtain the most active nanosilver.

Results showed that, when the algal powder and extracts were mixed with $\mathrm{AgNO}_{3}$ solution and incubated in dark the colour was turned into pale to dark brown colour which indicates the formation of silver nanoparticles, with intensity increasing during the period of incubation (Figures 2\&3). This colour difference was due to the reduction of silver ions (Swamy et al., 2014). Metallic nanoparticles scatter and absorb light at certain wavelengths due to a phenomena known as surface plasmon resonances (Noguez et al., 2007).

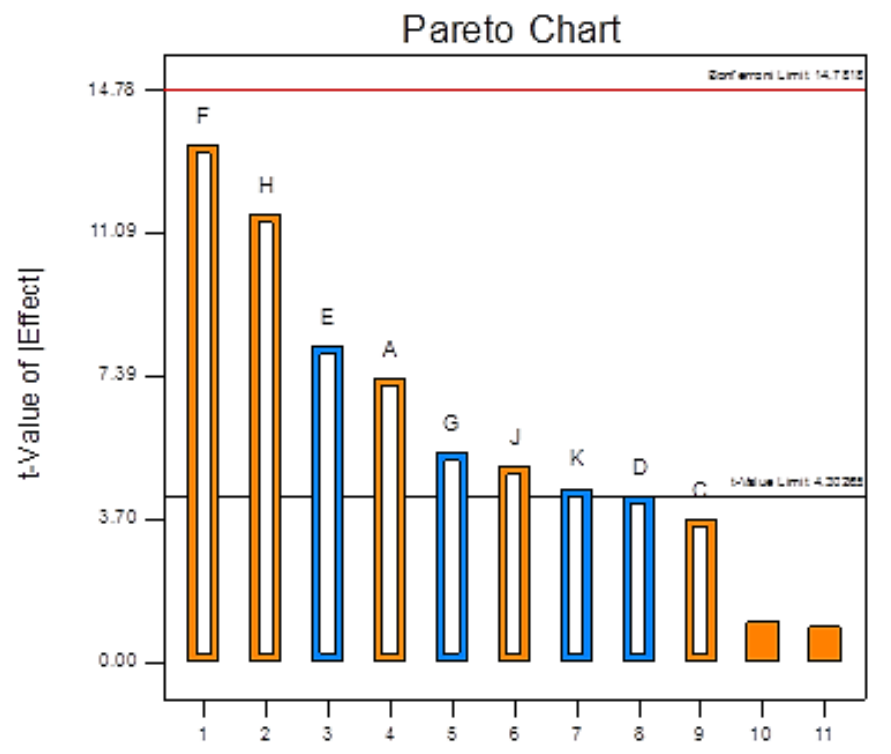

Figure 1 Pareto chart of eleven-factor effects on biological synthesis of AgNPs and its biological activity (IZD).

Table 2 Plackett-Burman experimental design with the response (Inhibition zone diameter) IZD- mm

\begin{tabular}{|c|c|c|c|c|c|c|c|c|c|c|c|c|}
\hline \multirow{2}{*}{ Trials } & \multicolumn{6}{|c|}{ Reducing source } & \multicolumn{5}{|c|}{$\begin{array}{c}\text { Metal and } \\
\text { Reaction conditions }\end{array}$} & \multirow{2}{*}{$\begin{array}{c}\text { Biological } \\
\text { activity of } \\
\text { AgNPs } \\
\text { against } \\
\text { E.coli } \\
\text { (IZD- mm }\end{array}$} \\
\hline & $\begin{array}{c}\text { Factor1 } \\
\text { A: } \\
\text { So.EE }\end{array}$ & $\begin{array}{c}\text { Factor } 2 \\
\text { B: } \\
\text { So.AE }\end{array}$ & $\begin{array}{c}\text { Factor } 3 \\
\text { C: } \\
\text { So.DAP }\end{array}$ & $\begin{array}{c}\text { Factor } 4 \\
\text { D: } \\
\text { Sp.DAP }\end{array}$ & $\begin{array}{c}\text { Factor } 5 \\
\text { E: } \\
\text { Sp.EE }\end{array}$ & $\begin{array}{c}\text { Factor } 6 \\
\text { F: } \\
\text { Sp.AE }\end{array}$ & $\begin{array}{c}\text { Factor7 } \\
\text { G: } \\
\text { Temp. }\end{array}$ & $\begin{array}{c}\text { Factor } 8 \\
\mathbf{H :} \\
\mathrm{AgNO}_{3}\end{array}$ & $\begin{array}{c}\text { Factor } 9 \\
\text { J: } \\
\text { pH value }\end{array}$ & $\begin{array}{c}\text { Factor10 } \\
\text { K: } \\
\text { Dark/light }\end{array}$ & $\begin{array}{c}\text { Factor11 } \\
\text { L: } \\
\text { RPM }\end{array}$ & \\
\hline 1 & -1 & -1 & -1 & +1 & -1 & +1 & +1 & -1 & +1 & +1 & +1 & $15 \pm 0.211$ \\
\hline 2 & -1 & +1 & -1 & +1 & +1 & -1 & +1 & +1 & +1 & -1 & -1 & $11 \pm 0.497$ \\
\hline 3 & +1 & +1 & -1 & -1 & -1 & +1 & -1 & +1 & +1 & -1 & +1 & $27 \pm 2.486$ \\
\hline 4 & +1 & -1 & +1 & +1 & -1 & +1 & +1 & +1 & -1 & -1 & -1 & $24 \pm 1.119$ \\
\hline 5 & +1 & +1 & -1 & +1 & +1 & +1 & -1 & -1 & -1 & +1 & -1 & $14 \pm 3.605$ \\
\hline 6 & -1 & +1 & +1 & -1 & +1 & +1 & +1 & -1 & -1 & -1 & +1 & $16 \pm 0.746$ \\
\hline 7 & +1 & -1 & +1 & +1 & +1 & -1 & -1 & -1 & +1 & -1 & +1 & $15 \pm 0.052$ \\
\hline 8 & +1 & -1 & -1 & -1 & +1 & -1 & +1 & +1 & -1 & +1 & +1 & $13 \pm 7.086$ \\
\hline 9 & -1 & +1 & +1 & +1 & -1 & -1 & -1 & +1 & -1 & +1 & +1 & $19 \pm 1.367$ \\
\hline 10 & +1 & +1 & +1 & -1 & -1 & -1 & +1 & -1 & +1 & +1 & -1 & $17 \pm 1.119$ \\
\hline 11 & -1 & -1 & -1 & -1 & -1 & -1 & -1 & -1 & -1 & -1 & -1 & $13 \pm 1.492$ \\
\hline 12 & -1 & -1 & +1 & -1 & +1 & +1 & -1 & +1 & +1 & +1 & -1 & $21 \pm 1.740$ \\
\hline
\end{tabular}

+1 and -1 explained the high and low levels of variables according to Table (1). Values $=$ Mean \pm SD.

Table 3 Plackett-Burman design analysis.

\begin{tabular}{lccccc}
\hline Source & $\begin{array}{c}\text { Sum of } \\
\text { Squares }\end{array}$ & df & $\begin{array}{c}\text { Mean } \\
\text { Square }\end{array}$ & F-value & $\begin{array}{c}\text { P-value } \\
\text { Prob>F }\end{array}$ \\
\hline Model & 2026.88 & 9 & 225.32 & 59.02 & $\begin{array}{c}0.0165 \\
\text { significant }\end{array}$ \\
A- So.EE & 201.55 & 1 & 202.54 & 52.96 & 0.0178 \\
C- So.DAP & 49.84 & 1 & 49.84 & 12.54 & 0.0665 \\
D- Sp.DAP & 67.65 & 1 & 69.64 & 16.29 & 0.0505 \\
E- Sp.EE & 250.17 & 1 & 251.17 & 65.90 & 0.0145 \\
F- Sp.AE & 669.50 & 1 & 670.51 & 177.60 & 0.0055 \\
G- Temperature & 108.81 & 1 & 108.81 & 28.27 & 0.0324 \\
H- AgNO & 502.11 & 1 & 503.11 & 133.01 & 0.0073 \\
J- pH value & 94.77 & 1 & 96.77 & 24.52 & 0.0369 \\
K- Incubation & 75.50 & 1 & 75.50 & 19.11 & 0.0462 \\
conditions & 7.52 & 2 & 2.95 & & \\
Residual & 2035.49 & 11 & & & \\
Cor Total & 1 & & & &
\end{tabular}

Std. Dev. $=1.96$, Mean= 14.06, R-Squared= 0.9863, Adj R-Squared $=0.9597$ Pred R-Squared $=0.8972$, (factors L- Incubation period \& B- So.AE were removed where, Prob $>|t|=0.1000$ and 0.4720 , respectively)

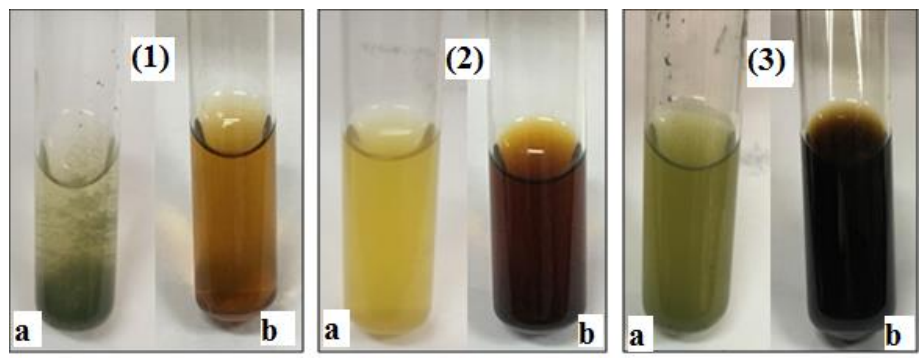

Figure 2 Biosynthesis of silver nanoparticles by Scenedesmus obliquus with different methods, (1) Dried algal powder, (2) Aqueous extract, (3) Ethanol extract, before (a) and after (b) exposure to silver nitrate solution for $24 \mathrm{~h}$. 


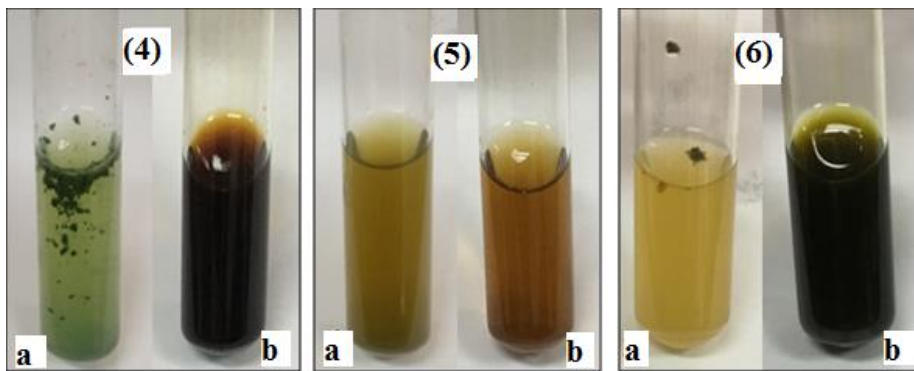

Figure 3 Biosynthesis of silver nanoparticles by Spirulina platensis with different methods, (4) Dried algal powder, (5) Aqueous extract, (6) Ethanol extract, before (a) and after (b) exposure to silver nitrate solution for $24 \mathrm{~h}$

\section{Characterization of silver nanoparticles}

\section{UV-Visible Spectroscopy}

Formation of colloidal silver nanoparticles can be followed by changes of UVVis absorption. The UV-vis absorption spectrum of $S$. obliquus powder and extracts showed a definite peak determined at 421 and $427 \mathrm{~nm}$ for aqueous and ethanol extracts respectively, indicating the formation of AgNPs. Similar results were observed by Sinha et al. (2015) who revealed absorption peak of AgNps at $445 \mathrm{~nm}$ using aqueous extract of green alga Pithophora oedogonia. Where a weak peak observed at $398 \mathrm{~nm}$ with algal powder showed that not all metals have been reduced Figure 4. Synthesized AgNps from S. platensis powder showed absorbance peak at 362 and abroad beak from 384 to $499 \mathrm{~nm}$ with algal aqueous extract, but it showed a sharp distinct beak at $418 \mathrm{~nm}$ with the ethanol extract Figure 5. According to Ravindra and Rajasab, (2014) the obtained peaks emphasized a surface plasmon resonance (SPR) that has already been formed for different metal nanoparticles with size in range from 2 to $100 \mathrm{~nm}$.

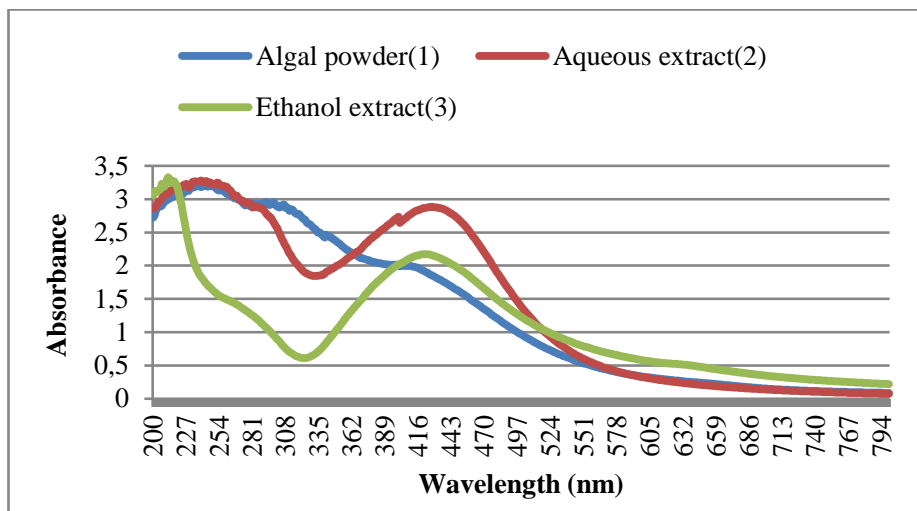

Figure 4 UV absorbance of AgNPs biosynthesized by Scenedesmus obliquus powder (1), aqueous extract(2) and ethanol extract(3).

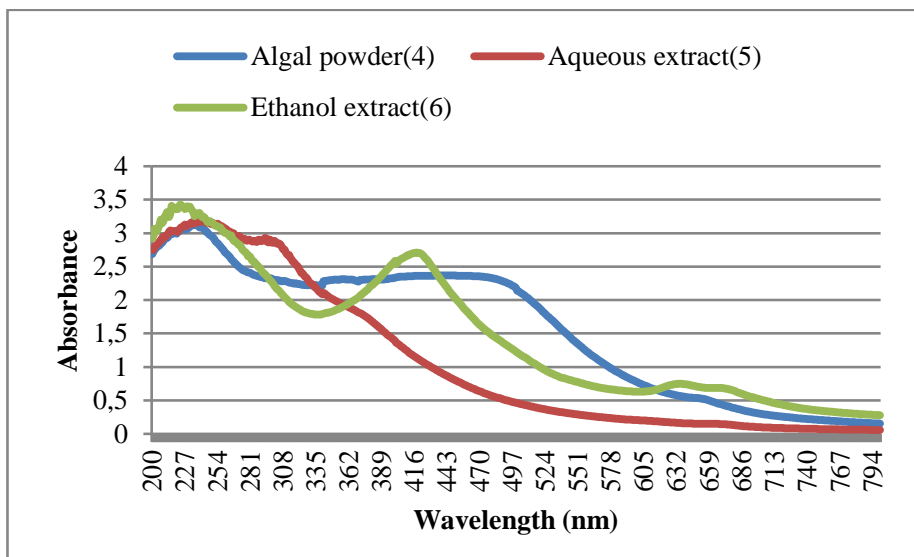

Figure $5 \mathrm{UV}$ absorbance of AgNPs biosynthesized by Spirulina platensis powder (4), aqueous extract (5) and ethanol extract (6).

\section{Transmission electron microscopy (TEM) of AgNPs}

Transmission electron microscopy of AgNPs synthesized by $S$. obliquus and $S$. platensis provided information on morphology and size of the AgNPs (Patel $\boldsymbol{e} t$ al., 2015). TEM micrograph showed that the shapes and sizes varied significantly among the species used and also the technique of biosynthesis (Figures 6\&7). TEM images of AgNPs synthesized by powder, aqueous and ethanol extracts of S. obliquus were showed in Figure $\mathbf{6}$ a, b, c. Results have revealed that the particles are well dispersed without aggregation and have a spherical shape in three methods. Where, the particle size was varied from 2.83 to $22.66 \mathrm{~nm}$ with powder, in ranges from 7.75 to $18.05 \mathrm{~nm}$ with aqueous extract and AgNPs biosynthesized from ethanol extract were all shown to be smaller ranging from 3.67 to $9.52 \mathrm{~nm}$ diameter.

Results in Figure $\mathbf{7 a}, \mathbf{b}, \mathbf{c}$ showed that the shapes of the particles included spherical, irregular and some aggregations. The spherical shape was predominant in the case of S. platensis ethanol extract with average sizes of the particles from 3.68 to $7.32 \mathrm{~nm}$, similar results also were discussed by Patel $\boldsymbol{e t}$ al. (2015) who reported the formation of the smallest particles of $13 \mathrm{~nm}$ diameter in the presence of C-phycocyanin isolated from Spirulina. Some irregular clusters of particles were formed by $S$. platensis powder, these results agree with nanoparticles formed by Synechocystis sp. and Anabaena sp. (Morones et al., 2005). TEM measurements of the AgNPs biosynthesized from S. platensis aqueous extract showed well dispersed nanoparticles with average size from 13.74 to $27.17 \mathrm{~nm}$ diameter with appearance of little irregular forms.

These results indicated that the powder, aqueous and ethanol extracts of both algae can change the size and shape of the silver nanoparticles, which indicated the effect of the bioactive constituents of the studied algae as reducing and controlling agents (Alenazi, 2013).

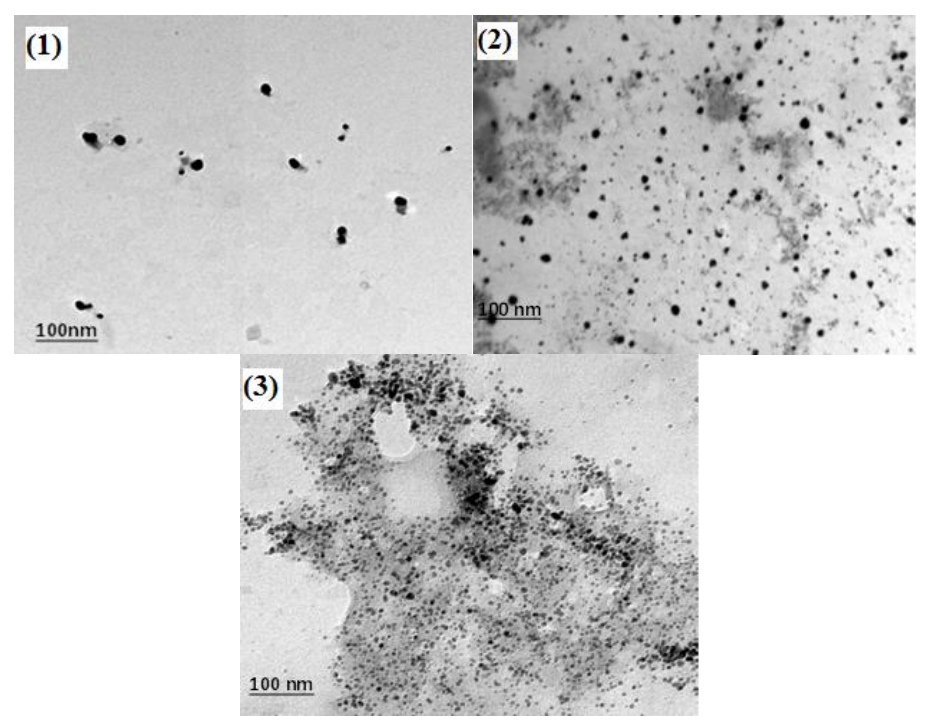

Figure 6 TEM of AgNPs biosynthesized by Scenedesmus obliquus powder (1), aqueous extract (2) and ethanol extract (3). 

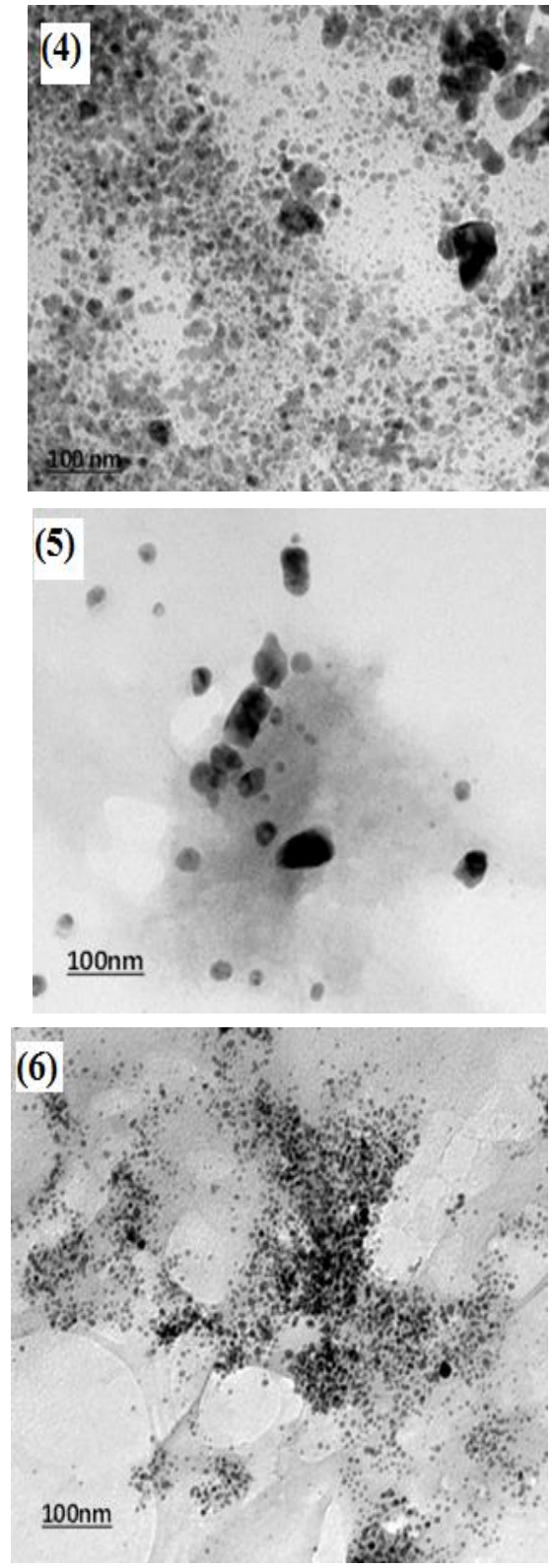

Figure 7 TEM of AgNPs biosynthesized by Spirulina platensis powder (4), aqueous extract (5) and ethanol extract(6).

\section{FTIR analysis of AgNPs synthesized by S. obliquus and S. platensis}

The functional groups which may be responsible for biosynthesis and nanoparticles stabilization, was detected by using Fourier Transforms Infrared Spectroscopy (FTIR). Results in Figure 8a, b showed bands in different regions of the spectrum. The certain common absorption band, at 3444 and $3436 \mathrm{~cm}^{-1}$ were characteristically vibrational $(\mathrm{N}-\mathrm{H})$ frequencies of amide I and amide II of protein. Vibrational peaks at 2117 and $2927 \mathrm{~cm}-1$ were characteristically vibrational frequencies $(\mathrm{O}-\mathrm{H})$; hydroxyl groups $(\mathrm{OH})$ are very abundant in polysaccharides which are mainly responsible for the metal reduction (Narayanan and Sakthivel, 2011).

Biological components are known to interact with the silver salt as well as the polysaccharides and proteinaceous matters were mediated their reduction to nano-particles (Bar et al., 2009).

Obtained result was in agreement with Sanghi and Verma (2009) who showed that, the common band at about 1639 and $1635 \mathrm{~cm}^{-1}$ corresponding to carbonyl vibrations in aldehydes, ketones and carboxylic acids, indicating the reduction of the silver ions is coupled to the oxidation of the hydroxyl groups in ethanol algal extract. As mentioned by Kannan et al. (2013), the vibrational frequencies for and $\mathrm{t}(\mathrm{C}-\mathrm{O}-\mathrm{C})$ and $\mathrm{t}(\mathrm{C}-\mathrm{O})$ were observed in the spectra of the extracts at $(1430$ 1427) and $(1270,1267) \mathrm{cm}-1$. An alkyl halide can be expected at 532 and 524 $\mathrm{cm}^{-1}$.
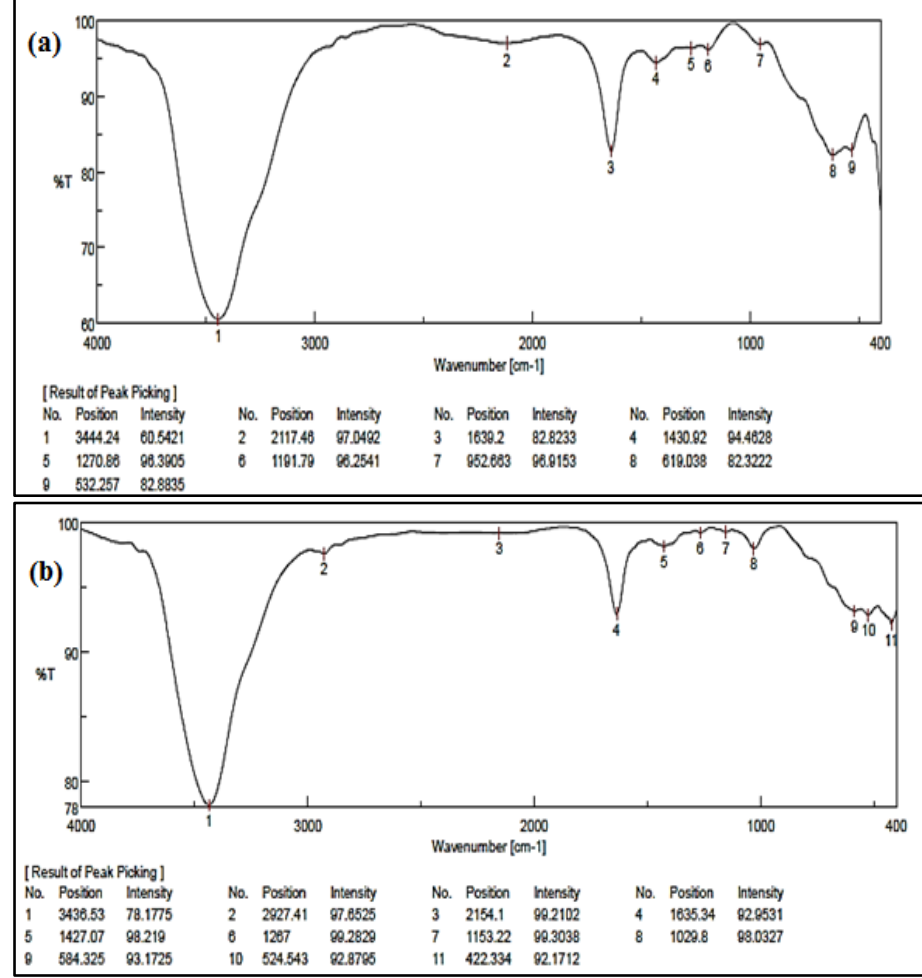

Figure 8 FTIR spectra of synthesized AgNPs using Scenedesmus obliquus (a) and Spirulina platensis (b) ranging from $4000-400 \mathrm{~cm}^{-1}$

\section{Analysis of antibacterial activity}

The antibacterial activity of $S$. obliquus silver nanoparticles formed by different methods including; the algal powder (1), aqueous extract(2) and ethanol extract (3) was confirmed in all with different zones of inhibition (Figure 9). Results in Table 4 indicated that the nanoparticles formed by method 1 and 3 were most effective against Gram-positive and Gram-negative bacteria (IZD from 20 to 26 $\mathrm{mm}$ ) than that formed by method 2 (IZD ranging from 18 to 20mm). Silver nanoparticles biosynthesized by $S$. obliquus had low effects against Gramnegative bacteria. On the other hand, the silver nanoparticles biosynthesized by fresh water green alga Pithophora oedogonia (Mont.) killed the Gram-negative bacteria more rapidly than Gram-positive bacteria (Sinha et al., 2015).

Silver nanoparticles biosynthesized by $S$. platensis aquoeus extract (5) and ethanol extract (6) showed inhibition zone against all studied Gram-positive and negative strains $(17-25 \mathrm{~mm})$, except that formed by algal powder (4) did not show any antibacterial activity against four studied bacterial strains. Also Patel $\boldsymbol{e t}$ al. (2015) reported no antibacterial activity for nanoparticles synthesized by the cyanobacterium Limnothrix sp. 3721. As mentioned previously by Matsumura et al. (2003) who showed the inhibitory result of silver nanoparticles on bacteria is mainly due to the elevated affinity of silver towards sulfur and phosphoruscontaining proteins on the bacterial cell membrane that affects the bacterial cell viability and inhibits the enzyme functions. Other studies of (Abd El Aty et al., 2020) and (Abd El Aty and zohair, 2020) prepared silver nanocomposite from fungal and bacterial sources with broad spectrum antimicrobial activity against Gram negative, Gram positive bacteria, pathogenic yeast and fungi. 
Table 4 Antimicrobial activities of six (1-6) biosynthesized AgNPs

Inhibition zone diameter (IZD)*

(mm)

\begin{tabular}{|c|c|c|c|c|c|c|c|c|c|}
\hline \multirow{3}{*}{$\begin{array}{l}\text { AgNps } \\
\text { source }\end{array}$} & \multirow{3}{*}{$\begin{array}{c}\text { No. of } \\
\text { sampl } \\
\text { es }\end{array}$} & \multirow{2}{*}{\multicolumn{2}{|c|}{ Gram positive bacteria }} & \multirow{2}{*}{\multicolumn{2}{|c|}{$\begin{array}{c}\text { Gram negative } \\
\text { bacteria }\end{array}$}} & \multirow{2}{*}{\multicolumn{2}{|c|}{ Yeast }} & \multirow{2}{*}{\multicolumn{2}{|c|}{ Fungi }} \\
\hline & & & & & & & & & \\
\hline & & $\begin{array}{c}\text { S. aureus } \\
\text { ATCC29213 }\end{array}$ & $\begin{array}{c}\text { B. subtilis } \\
\text { ATCC6633 }\end{array}$ & $\begin{array}{c}E . \text { coli } \\
\text { ATCC25922 }\end{array}$ & $\begin{array}{c}\text { S. enterica } \\
\text { ATCC25566 }\end{array}$ & $\begin{array}{c}\text { C. albicans } \\
\text { ATCC10321 }\end{array}$ & $\begin{array}{c}\text { C.tropicalis } \\
\text { ATCC750 }\end{array}$ & $\begin{array}{l}\text { A.niger } \\
\text { NRC53 }\end{array}$ & $\begin{array}{l}\text { F. solani } \\
\text { NRC15 }\end{array}$ \\
\hline \multirow{3}{*}{ S. obliquus } & 1 & $24 \pm 1.41$ & $26 \pm \mathbf{0 . 7 0}$ & $20 \pm \mathbf{0 . 0 9}$ & $22 \pm \mathbf{0 . 7 0}$ & $26 \pm 2.41$ & $22 \pm \mathbf{0 . 7 1}$ & $23 \pm 1.41$ & $18 \pm \mathbf{0 . 7 0}$ \\
\hline & 2 & $18 \pm \mathbf{0 . 7 0}$ & $20 \pm 2.41$ & $18 \pm \mathbf{0 . 7 0}$ & $20 \pm 1.41$ & $25 \pm \mathbf{0 . 7 1}$ & $17 \pm \mathbf{1 . 2 1}$ & $20 \pm 1.42$ & $15 \pm \mathbf{2 . 1 0}$ \\
\hline & 3 & $25 \pm \mathbf{0 . 7 1}$ & $25 \pm \mathbf{0 . 7 1}$ & $20 \pm \mathbf{0 . 7 0}$ & $22 \pm \mathbf{0 . 7 1}$ & $24 \pm 1.41$ & $21 \pm \mathbf{0 . 7 0}$ & $21 \pm \mathbf{3 . 1 0}$ & $16 \pm 1.42$ \\
\hline \multirow{3}{*}{ S. platensis } & 4 & $00 \pm \mathbf{0 0}$ & $00 \pm \mathbf{0 0}$ & $00 \pm \mathbf{0 0}$ & $00 \pm \mathbf{0 0}$ & $22 \pm \mathbf{2 . 1 0}$ & $15 \pm \mathbf{0 . 7 2}$ & $17 \pm \mathbf{0 . 7 0}$ & $15 \pm \mathbf{0 . 7 1}$ \\
\hline & 5 & $22 \pm \mathbf{0 . 7 1}$ & $24 \pm \mathbf{1 . 2 1}$ & $22 \pm \mathbf{2 . 4 1}$ & $25 \pm 1.21$ & $30 \pm \mathbf{0 . 7 0}$ & $28 \pm 1.42$ & $28 \pm 1.21$ & $25 \pm 1.41$ \\
\hline & 6 & $17 \pm \mathbf{2 . 1 0}$ & $20 \pm 1.41$ & $17 \pm \mathbf{0 . 7 1}$ & $18 \pm \mathbf{2 . 4 1}$ & $25 \pm \mathbf{0 . 7 0}$ & $25 \pm \mathbf{0 . 7 0}$ & $20 \pm \mathbf{2 . 1 0}$ & $17 \pm \mathbf{1 . 4 2}$ \\
\hline
\end{tabular}

*Inhibition Zone Diameter (IZD) expressed as Mean \pm SD in (mm).

\section{Analysis of antifungal activity}

Antifungal activity of all AgNPs $(1,2,3,4,5$ and 6) synthesized by both algal strains was tested against two yeast strains and two filamentous fungi (Figure 10). Results in Table 4 showed that $S$. obliquus silver nanoparticles (1, 2, and 3 ) exhibited wide range of antifungal activities. Maximum zone of inhibition was found against $C$. albicans $(24-26 \mathrm{~mm})$ and followed by A.niger $(20-23 \mathrm{~mm})$ But they have moderate fungicidal activity against $F$. solani.

Silver nanoparticles biosynthesized by $S$. platensis aquoeus extract (5) and ethanol extract (6) showed antifungal effects better than that obtained from the algal powder (4) (Table 4). The well dispersed nanoparticles with average size ranging from 13.74 to $27.17 \mathrm{~nm}$ diameter formed by S.platensis aquoeus extract (5) was the most effective against different fungal strais $(25-30 \mathrm{~mm})$.

As mentioned previously by Dorau et al. (2004) who reported the antifungal potentialities mainly due to the inactivation of sulfhydryl groups in the fungal cell wall and disruption of membrane bound enzymes and lipids resulting in lyses of cell.

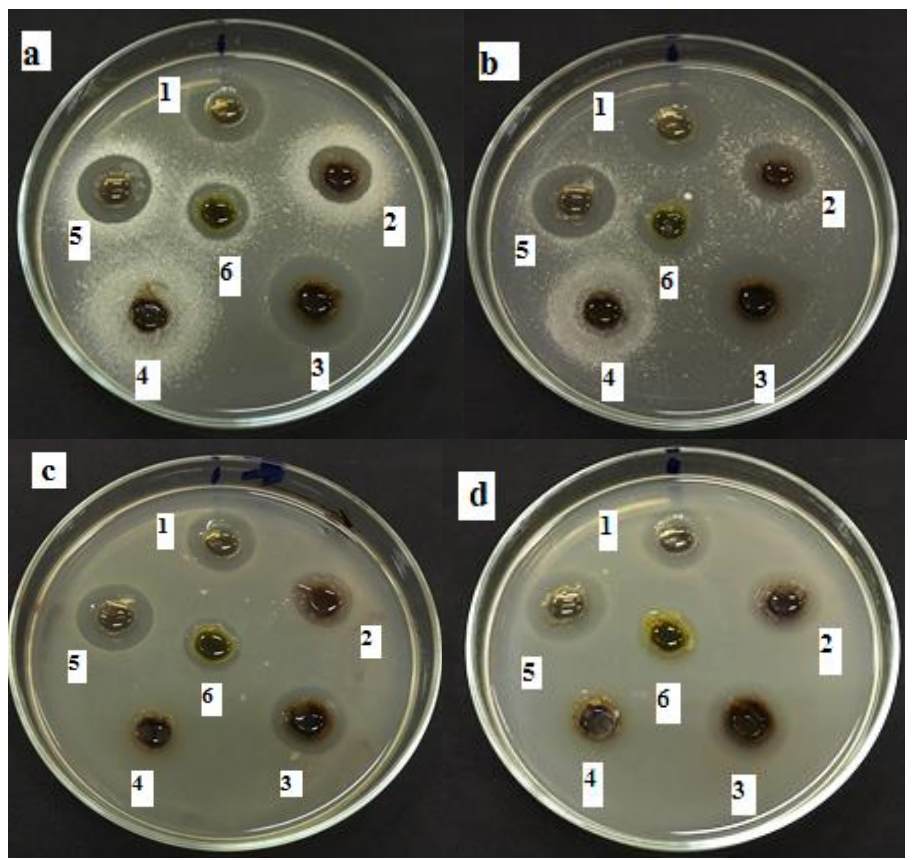

Figure 9 Antibacterial activity of Scenedesmus obliquus silver nanoparticles $(1,2,3)$ and Spirulina platensis silver nanoparticles (4,5,6). Against Gram-positive S. aureus (a), B. subtilis (b) and Gram-negative E. coli (c), S. enterica (d).

\section{Analysis of antitumor activity}

Silver nanoparticles biosynthesized from green alga (S. obliquus) and blue green alga ( $S$. platensis) were screened for their cytotoxic activities against Hepatocellular carcinoma cell line (HepG2) and breast cancer cell line (MCF-7) using the MTT assay (El-Menshawi et al., 2010). Initially, six different AgNPs were prepared using algal powder, aqueous and ethanol extracts. The results showed that the AgNPs prepared from ethanol extract of the blue green alga $S$ platensis was the most active, which possessed highly cytotoxic effect against HepG2 and MCF-7 cell lines (cytotoxicity $=81 \%$ and $71 \%$ respectively) (Figure 11) and with $\mathrm{IC}_{50}$ values 62.1 and $56.2 \mathrm{ug} / \mathrm{mL}$ respectively (Table 5). On the other hand, AgNPs biosynthesized by algal powder and aqueous extract showed weak cytotoxic effect in all two cell lines tested (Figure 11).

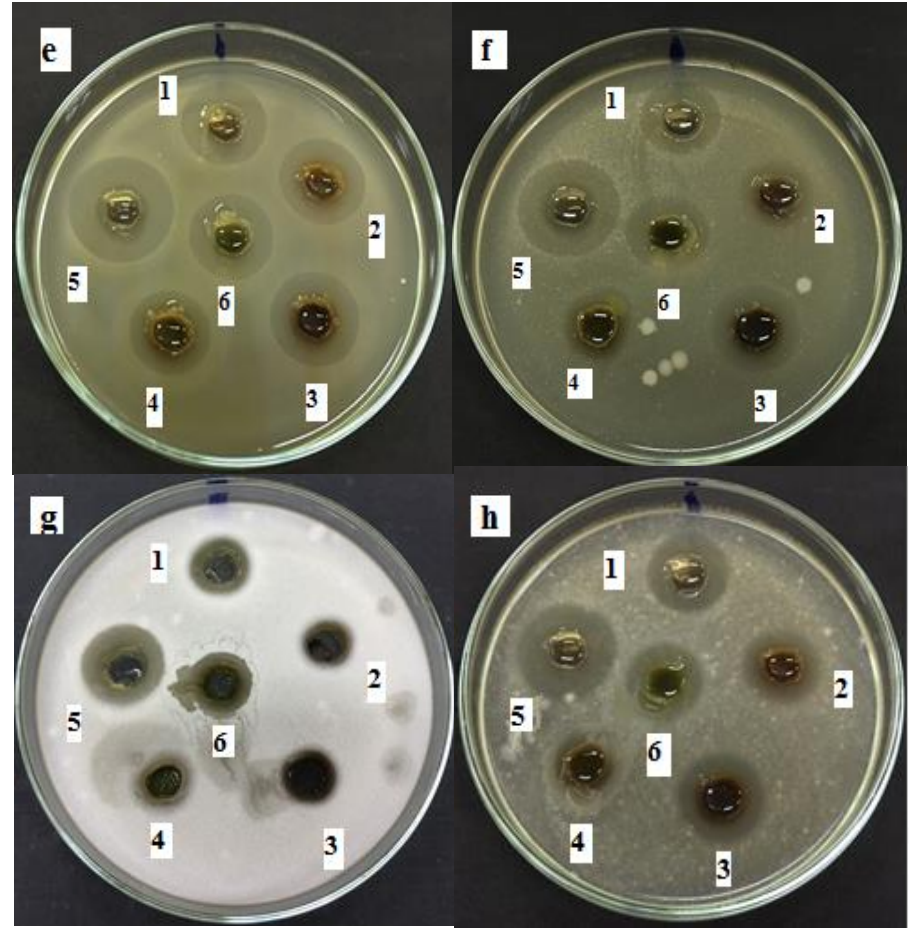

Figure 10 Antifungal activity of Scenedesmus obliquus silver nanoparticles $(1,2,3)$ and Spirulina platensis silver nanoparticles $(4,5,6)$. Against yeast $C$. albicans (e), C. trobicalis (f) and filamentous fungi $F$. solani $(\mathrm{g})$, A. niger $(\mathrm{h})$.

On the other hand, all S.obliquus silver nanoparticles prepared from (algal powder, aqueous and ethanol extracts) showed little or no cytotoxic effects on tested cancer cells. Our results indicated that, the biosynthesized AgNPs from the blue green alga $S$. platensis ethanol extract with spherical shape and average sizes in ranged from 3.68 to $7.32 \mathrm{~nm}$, was a potential alternative therapeutic approach in certain types of cancer.

Table 5 IC50 values of the most active biosynthesized AgNPs against two cancer cells

\begin{tabular}{lll}
\hline \multirow{2}{*}{ Entry } & \multicolumn{3}{l}{ IC50 ug/ml } \\
\cline { 2 - 3 } & HepG2 & MCF-7 \\
\hline $\begin{array}{l}\text { AgNPs biosynthesized by } \\
\text { S. platensis } \text { ethanol extract(6) }\end{array}$ & $62.1 \pm 1.5$ & $56.2 \pm 1.8$ \\
\hline
\end{tabular}



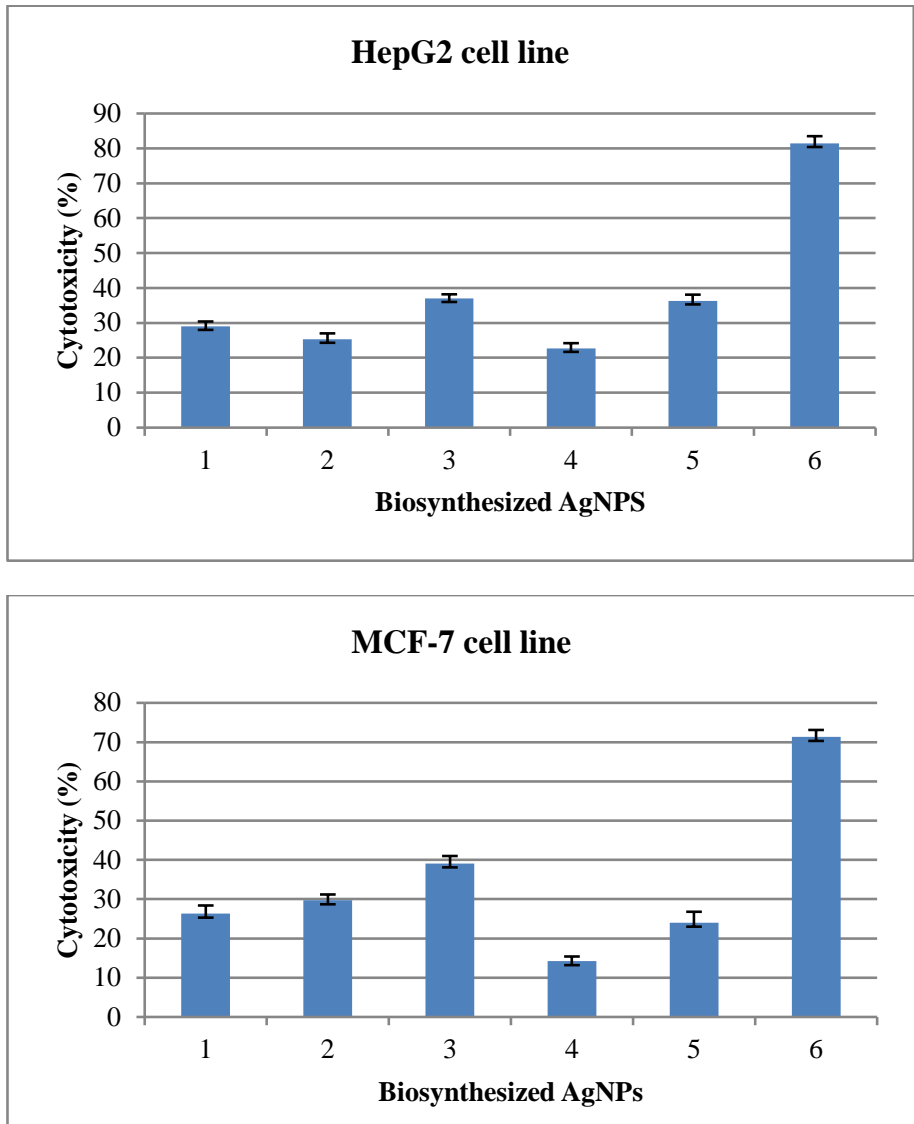

Figure 11 Cytotoxicity of silver nanoparticles biosynthesized from green alga Scenedesmus obliquus $(1,2,3)$ and blue green alga Spirulina platensis $(4,5,6)$ at $100 \mathrm{ug} / \mathrm{mL}$

\section{CONCLUSION}

Among the noble metals silver is recommended in variable fields of medicine and biological system. PB experiment and the obtained data clearly indicate the dried powder and extracts of the algae S. obliquus and S. platensis can be used as an effective capping as well as the reducing agent for the synthesis of AgNPs. Analysis showed that nanoparticles (1-6) biosynthesized with different shapes and sizes depending on the species used and the method of biosynthesis. Six biosynthesized silver nanoparticles exhibited wide range of antimicrobial activity and high cytotoxic effect against HepG2 and MCF-7 cell lines especially for AgNPs prepared from ethanol extract of the blue green alga $S$. platensis.

Acknowledgement: The authors are sincerely thankful to National Research Centre and chemistry of natural and microbial products department.

\section{REFRENCES}

Abd El Aty, A.A.,\& Ammar, H.A. (2016). Potential characterization and antimicrobial applications of newly bio-synthesized silver and copper nanoparticles using the novel marine-derived fungus Alternaria tenuissima KM651985. Research Journal of BioTechnology. 11(8), 71-82.

Abd El Aty, A.A., Hamed, E.R., El-Beih, A.A., \& El-Diwany, A.I. (2016) Induction and enhancement of the novel marine-derived Alternaria tenuissima KM651985 laccase enzyme using response surface methodology: Application to Azo and Triphenylmethane dyes decolorization. Journal of Applied Pharmaceutical Science, 6 (04), 006-014. DOI: 10.7324/JAPS.2016.60402

Abd El Aty, A.A., Shehata, A.N., \& Shaheen, Th.I. (2018). Production and sequential optimization of Bacillus subtilis MF467279 pullulanase by statistical experimental designs and evaluation of its desizing efficiency. Biocatalysis and Agricultural Biotechnology,

14 ,

$375-385$.

https://doi.org/10.1016/j.bcab.2018.04.004

Abd El Aty, A.A., Mohamed, A.A., Zohair, M.M., \& Soliman, A.A.F. (2020) Statistically controlled biogenesis of silver nano-size by Penicillium chrysogenum MF318506 for biomedical application. Biocatalysis and Agricultural Biotechnology,

https://doi.org/10.1016/j.bcab.2020.101592

25 ,

101592.

Abd El Aty, A.A., \& Zohair, M.M. (2020). Green-synthesis and optimization of an eco-friendly nanobiofungicide from Bacillus amyloliquefaciens MH046937 with antimicrobial potential against phytopathogens. Environmental Nanotechnology, Monitoring \& Management, 14, 100309 https://doi.org/10.1016/j.enmm.2020.100309
Abdel-Raouf, N., Al-Enazi, N.M., Ibraheem, I.B.M., Alharbi, R.M.\& Alkhulaifi, M.M. (2018). Biosynthesis of silver nanoparticles by using of the marine brown alga Padina pavonia and their characterization. Saudi Journal of Biological Sciences. In Press. http://dx.doi.org/10.1016/j.sjbs.2018.01.007.

Abdel Wahab, W.A., Abd El Aty, A.A.\& Mostafa, F.A. (2018). Improvement of catalytic, thermodynamics and antifungal activity of constitutive Trichoderma longibrachiatum KT693225 exochitinase by covalent coupling to oxidized polysaccharides. International Journal of Biological Macromolecules. 112, 179 187. https://doi.org/10.1016/j.ijbiomac.2018.01.156

Alenazi, N.M. (2013). Biogenic synthesis of nanoparticles and their synergistic effect with some benthic marine macroalgal extracts isolated from Umluj (KSA) seashore against some pathogenic bacteria. Ph.D. Thesis, Collage of Scie., KSU, KSA., 83-90.

Bar, H., Bhui, D., Sahoo, G., Sarkar, P., Pyne, S.\& Misra, A. (2009). Green synthesis of silver nanoparticles using seed extract of Jatropha curcas. Colloids Surf. A: Physicochem. Eng. Aspects, 348, 212-216.

Con, T.H.\& Loan, D.K. (2011). Preparation of silver nano-particles and use as a material for water sterilization. Environ. Asia., 4, 62-66.

Dahl, J.A., Maddux, B.L., \& Hutchison, J.E. (2007). Toward greener nanosynthesis. Chem. Rev., 107, 2228-2269.

Dorau, B.\& Arang, R. (2004). Green F., Proceedings of the 2nd Wood-Frame Housing Durabili and Disaster Issues Conference, Forest Products Society, Las Vegas, NV, r 4-6, 133.

El-Menshawi, B.S., Fayad, W., Mahmoud, K., El-Hallouty, S.M., El-Manawaty, M.\& Olofsson, M.H., et al. (2010). Screening of natural products for therapeutic activity against solid tumors. Indian J. Exp. Biol. 48(3), 258-264.

Kannan, R.R.R., Arumugam, R., Ramya, D., Manivannan, K.,\& Anantharaman, P. (2013). Green synthesis of silver nanoparticles using marine macroalga Chaetomorpha linum. Appl. Nanosci. 3, 229-233.

Khlebtsov, N.G. \& Dykman, L.A. (2010). Optical properties and biomedical applications of plasmonic nanoparticles. J. Quant Spectrosc Radiat Transfer. $111,1-35$.

Kumar, P., Selvi, S.S.,\& Govindaraju, M. (2013). Seaweed-mediated biosynthesis of silver nanoparticles using Gracilaria corticata for its antifungal activity against Candida spp. Appl. Nanosci. 3, 495-500.

Matsumura Y., Yoshikata K., Kunisaki S.\& Tsuchido T. (2003). Mode of bactericidal action of silver zeolite and its comparison with that of silver nitrate, Appl. Environ. Microbiol., 69, 4278-4281.

Meena, R., Siddhanta, A.K., Prasad, K., Ramavat, B.K., Eswaran, K., Thiruppathi, S., Ganesan, M., Mantri, V.A.\& Subba Rao, P.V. (2007) Preparation, characterization and benchmarking of agarose from Gracilaria dura of Indian waters. Carbohydr. Polym., 69, 179-188.

Morones, J.R., Elechiguerra, J.L., Camacho, A., Holt, K., Kouri, J.B., Tamorez, J.T.\&Yacaman, M.J. (2005). The bactericidal effect of silver nanoparticles, Nanotechnology, 16, 2346-2353.

Muruganandam, S., Anbalagan, G.\& Murugadoss, G. (2014). Optical, electrochemical and thermal properties of $\mathrm{Co} 2$ ?- doped $\mathrm{CdS}$ nanoparticles using polyvinylpyrrolidone. Appl Nanosci. http://dx.doi.org/10. 1007/s13204-0140313-6.

Narayanan, K.\& Sakthivel, N. (2011). Green synthesis of biogenic metal nanoparticles by terrestrial and aquatic phototrophic and heterotrophic eukaryotes and biocompatible agents. Adv. Colloid Interface Sci. 10, 1-21.

Noguez, C. (2007). Surface plasmons on metal nanoparticles: the influence of shape and physical environment. J. Phys. Chem. C111, 3806-3819.

Patel, V., Berthold, D., Puranik, P.\& Gantar, M. (2015). Screening of cyanobacteria and microalgae for their ability to synthesize silver nanoparticles with antibacterial activity. Biotechnology Reports. 5, 112-119.

Paul, K., Bag, B.G.\& Samanta, K. (2014). Green coconut (Cocos nucifera Linn.) shell extract mediated size controlled green synthesis of polyshaped gold nanoparticles and its application in catalysis. Appl. Nanosci. 4, 769-775.

Plackett, R. L., \& Burman, J. P. (1946). The design of optimum multifactorial experiments. Biometrica. 33( 4), 305-325.

Prasad, T.N., Kambala, V.S.R.\& Naidu, R. (2013). Phyconanotechnology: synthesis of silver nanoparticles using brown marine algae Cystophora moniliformis and their characterisation. J. Appl. Phycol. 25, 177-182.

Ravichandran, R. (2009). Nanoparticles in drug delivery: potential green nanobiomedicine applications. Int. J. Nanotechnol. Biomed. 1, 108-130.

Ravindra, B.K.\& Rajasab, A.H. (2014). A comparative study on biosynthesis of silver nanoparticles using four different fungal species. Int. J. Pharm. Sci. 6, 372 376

Sanghi, R.\& Verma, P. (2009). Biomimetic synthesis and characterisation of protein capped silver nanoparticles. Bioresour. Technol. 100, 501-504.

Shaheen, Th. I.\& Abd El Aty, A.A. (2018). In-situ green myco-synthesis of silver nanoparticles onto cotton fabrics for broad spectrum antimicrobial activity. International Journal of Biological Macromolecules. 118, 2121-2130. https://doi.org/10.1016/j.ijbiomac.2018.07.062

Sinha, S.N.\& Paul, D. (2014). Eco-friendly green synthesis and spectrophotometric characterization of silver nanoparticles synthesized using some common Indian spices. Int. J. Green Herbal Chem. 3, 401-408. 
Sinha, S.N., Paul, D., Halder, N., Sengupta, D.\& Patra, S.K. (2015). Green synthesis of silver nanoparticles using fresh water green alga Pithophora oedogonia (Mont.) Wittrock and evaluation of their antibacterial activity. Appl. Nanosci. 5,703-709. http://dx.doi.org/10.1007/s13204-014-0366-6.

Swamy, M.K., Sudipta, K.M., Jayanta, K.\& Balasubramanya, S. (2014). The green synthesis, characterization, and evaluation of the biological activities of silver nanoparticles synthesized from Leptadenia reticulata leaf extract. Appl. Nanosci. http://dx.doi.org/10.1007/s13204-014-0293-6.

Venkatesan, P.\& Santhanalakshmi, J. (2014). Synthesis, characterization and catalytic activity of gold and silver nanoparticles in the biosensor application. $J$. Exp. Nanosci., 9, 293-298. 